\title{
Effect of Lateral Wedge Insole on Pain and Function in Medial Compartment Osteoarthritis Knee- An Evidence Based Study
}

\author{
Mausmee Hemantbhai Rajwadi ${ }^{1}$, Yagna Unmesh Shukla ${ }^{2}$ \\ ${ }^{1}$ M.P.T. (Orthopedics), ${ }^{2}$ M.P.T. (Musculoskeletal), Ph.D. Senior Lecturer, \\ Government Spine Institute and Government Physiotherapy College, Civil Hospital, Asarwa, Ahmedabad.
}

Corresponding Author: Mausmee Hemantbhai Rajwadi

\begin{abstract}
Background: Osteoarthritis is the second most common rheumatologic problem \& nearly $80 \%$ of population shows OA among the patient who claimed for knee pain and limitation in movement, out of which approximately $25 \%$ cannot perform their major daily activities of life.(WHO 2019)As per recent study, prevalence of knee OA in India is $28.7 \%$ with medial compartment more involved than lateral.

Purpose: To study the evidences regarding effect of lateral wedge insole patient with medial compartment osteoarthritis of knee on pain and function.

Methodology: The study was conducted according to Preferred Reporting Items for systematic reviews and meta-analysis guidelines. Evidences selected since year 2005February 2019 from PubMed, Google Scholar, Physiotherapy Evidence Database(PEDro), ResearchGate, ScienceDirect, Wiley's online library and The Cochrane library. Key words used were: Lateral wedge insole, knee osteoarthritis, Pain and Function. Analysis was done using 2 scales: PEDro scale and Centre for Evidence-Based Medicine Levels of Evidence Scale. Total 200 articles were found, out of which 23 articles were relevant and from those 16 articles were included in the study and other articles were excluded as per eligibility criteria.

Results: 13 studies were shown that lateral wedge insole is effective treatment for reducing pain and improving function. (Level of evidence$1 a, 1 b, 2 b) 3$ studies were showed that lateral wedge insole have none or same effect as other conservative treatment in knee osteoarthritis. (Level of evidence-1a,1b,2b).
\end{abstract}

Conclusion: Based on the evidences taken from search engines: PubMed, Google Scholar, Physiotherapy Evidence Database(PEDro), ResearchGate, ScienceDirect, Wiley's online library and The Cochrane library of year 20052019 and analysis of all concluded that, full length wedge insole is found to be an effective conservative treatment for reducing pain and improving function in medial compartment knee osteoarthritis.

Key Words: Lateral wedge insole, knee osteoarthritis, pain and function.

\section{INTRODUCTION}

Osteoarthritis (OA), also known as degenerative joint disease or osteoarthritis, is the most common form of arthritis and the leading source of physical disability with severely impaired quality of life in people. ${ }^{[8]}$ Osteoarthritis is a disorder of cartilage degradation synovial inflammation, osteophytes formation, thinning of joints space and sub-chondral sclerosis. ${ }^{[1]}$

Globally knee OA ranks $4^{\text {th }}$ most common cause of incapability in women and 8th in men. ${ }^{[1]}$ India impact, nearly $80 \%$ of population shows OA among the patient who claimed for knee pain, out of which approximately $20 \%$ reported incapability in daily activities and around $11 \%$ need peculiar care. Approximately $40 \%$ population of more than 70 years shows $\mathrm{OA}$, in which nearly $2 \%$ have severe knee pain and disability. ${ }^{[2]}$ As per recent study a prevalence of knee OA is $28.7 \%$, this varies 

osteoarthritis knee- an evidence based study.

slightly in the individual states- Agra (35.5\%), Bangalore (26.6\%), Kolkata (33.7\%), Dehradun (27.2\%), and Pune $(21.7 \%){ }^{[3]}$

Foot Posture has been suggested to be related to the development of lower limb musculoskeletal conditions because of it's potential influence on the mechanical alignment and dynamic function of the lower limb. ${ }^{[12]}$ Lateral wedge insole placed under the sole of the foot and angulated so that it is thicker over the lateral than medial edge, transferring loading during weight bearing from the medial to the lateral knee compartment and reduce pain and improve functional activity. ${ }^{[11]}$

\section{METHODOLOGY}

Study Type: This is an Evidence Based Study was conducted according to Preferred Reporting Items for Systematic Reviews and Meta-analysis (PRISMA) guidelines (Figure 1).

Search strategy: The search engines used for the finding out appropriate articles were: PubMed, Google Scholar, Physiotherapy Evidence Database (PEDro), Research Gate, Science Direct, Wiley's online library and The Cochrane library

Key words used for the search were: knee osteoarthritis, lateral wedge insole, Pain and function.

Eligibility criteria: Articles were selected from last 15 years (2004 April 2019).Total 200 articles were found, out of which 19 articles were relevant and from those 16 articles were included in the study (Table 1). Other articles were excluded because it didn't involve population of low back pain and outcome measures were other than pain and function.

(1).

Table 1: Characteristics of included studies

\begin{tabular}{|c|c|c|c|c|c|}
\hline $\begin{array}{l}\text { Sr } \\
\text { No. }\end{array}$ & Title & $\begin{array}{l}\text { Study Design } \\
\text { \&Duration }\end{array}$ & $\begin{array}{l}\text { Articles Or Sample } \\
\text { Size }\end{array}$ & $\begin{array}{l}\text { Outcome } \\
\text { Measures }\end{array}$ & $\begin{array}{l}\text { Pedro And } \\
\text { Level Of } \\
\text { Evidence }\end{array}$ \\
\hline 1 & $\begin{array}{l}\text { The optimal degree of lateral wedge } \\
\text { insoles for reducing knee joint load : a } \\
\text { systemic review and meta-analysis }{ }^{[14]}\end{array}$ & $\begin{array}{l}\text { Systemic review } \\
\text { and meta-analysis }\end{array}$ & $\begin{array}{l}15 \text { studies with total } 415 \\
\text { participants }\end{array}$ & $\begin{array}{l}\text { First EKAM } \\
\text { VAS } \\
\text { WOMAC } \\
\end{array}$ & $1 \mathrm{a}$ \\
\hline 2 & $\begin{array}{l}\text { Is the Wedged Insole an Effective } \\
\text { Treatment Option When Compared with a } \\
\text { Flat (Placebo) Insole: A Systematic } \\
\text { Review and Meta-Analysis }\end{array}$ & $\begin{array}{l}\text { A Systemic review } \\
\text { and Meta-Analysis }\end{array}$ & 898 & $\begin{array}{l}\text { WOMAC } \\
\text { FTA }\end{array}$ & $1 \mathrm{a}$ \\
\hline 3 & $\begin{array}{l}\text { Ineffectiveness of lateral wedge insoles } \\
\text { on the improvement of pain and function } \\
\text { for medial knee osteoarthritis }{ }^{[16]}\end{array}$ & Meta-analysis & $\begin{array}{l}938 \text { total } \\
478 \text { with LWI and } 460 \\
\text { with set as control }\end{array}$ & WOMAC & $1 \mathrm{a}$ \\
\hline 4 & $\begin{array}{l}\text { Lateral Wedge Insoles as a Conservative } \\
\text { Treatment for Pain in Patients With } \\
\text { Medial Knee Osteoarthritis A Meta- } \\
\text { analysis }{ }^{[17]}\end{array}$ & Meta-analysis & 502 & $\begin{array}{l}\text { WOMAC } \\
\text { VAS }\end{array}$ & $1 \mathrm{a}$ \\
\hline 5 & $\begin{array}{l}\text { Feasibility of Lateral Wedge Insole v/s } \\
\text { Neutral Insole in combination with } \\
\text { Neuromuscular Training on Pain and } \\
\text { Function in patients with Medial } \\
\text { Compartment Osteoarthritis of Knee - a } \\
\text { Pilot Double Blinded Randomized } \\
\text { Control Trial }{ }^{[18]}\end{array}$ & $\begin{array}{l}\text { A randomized } \\
\text { controlled trial } \\
(6 \text { weeks })\end{array}$ & 10 in each & $\begin{array}{l}\text { TUG } \\
\text { VAS } \\
\text { WOMAC }\end{array}$ & $\begin{array}{l}10 / 10 \\
1 b\end{array}$ \\
\hline 6 & $\begin{array}{l}\text { The efficacy of a lateral wedge insole for } \\
\text { painful medial knee OA after } \\
\text { prescreening : A RCT }{ }^{[28]}\end{array}$ & $\begin{array}{l}\text { A randomized } \\
\text { controlled trial( } 8 \\
\text { weeks })\end{array}$ & 83 & $\begin{array}{l}\text { KOOS } \\
\text { WOMAC }\end{array}$ & $\begin{array}{l}10 / 10 \\
1 b\end{array}$ \\
\hline 7 & $\begin{array}{l}\text { A comparative study of the lateral wedge } \\
\text { insole shoe modification on the patients } \\
\text { with knee osteoarthritis. }{ }^{[29]}\end{array}$ & $\begin{array}{l}\text { Comparative } \\
\text { experimental study }\end{array}$ & 65 & WOMAC & $2 b$ \\
\hline 8 & $\begin{array}{l}\text { Knee and ankle biomechanics with lateral } \\
\text { wedges with and without a custom arch } \\
\text { support in those with medial knee } \\
\text { osteoarthritis and flat feet }{ }^{[27]}\end{array}$ & $\begin{array}{l}\text { A randomized } \\
\text { controlled trial }\end{array}$ & 26 & $\begin{array}{l}\text { VAS, } \\
\text { 3D Gait analysis }\end{array}$ & $\begin{array}{l}6 / 10 \\
1 \mathrm{~b}\end{array}$ \\
\hline 9 & $\begin{array}{l}\text { Clinical effect of lateral wedge arch } \\
\text { support insole in knee osteoarthritis- } \\
\text { double blind randomized study }{ }^{[20]}\end{array}$ & $\begin{array}{l}\text { A randomized } \\
\text { controlled trial } \\
(3 \text { months })\end{array}$ & 90 & KOOS & $\begin{array}{l}8 / 10 \\
1 \mathrm{~b}\end{array}$ \\
\hline 10 & $\begin{array}{l}\text { A comparison of the biomechanical effect } \\
\text { of valgus knee braces and lateral wedge } \\
\text { insoles in patients with knee osteoarthritis } \\
{[26]}\end{array}$ & $\begin{array}{l}\text { Pre-post } \\
\text { intervention } \\
\text { Comparative study } \\
(2 \text { weeks) }\end{array}$ & 28 & $\begin{array}{l}\text { VAS } \\
\text { WOMAC }\end{array}$ & $\begin{array}{l}7 / 10 \\
2 b\end{array}$ \\
\hline
\end{tabular}


Mausmee Hemantbhai Rajwadi et.al. Effect of lateral wedge insole on pain and function in medial compartment osteoarthritis knee- an evidence based study.

\begin{tabular}{|c|c|c|c|c|c|}
\hline \multicolumn{6}{|c|}{ Table 1: Continued... } \\
\hline 11 & $\begin{array}{l}\text { Lateral wedge insole for knee } \\
\text { osteoarthritis: } \\
\text { Rct }^{[19]}\end{array}$ & $\begin{array}{l}\text { A randomized } \\
\text { controlled trial }(8 \\
\text { weeks })\end{array}$ & 58 & $\begin{array}{l}\text { VAS } \\
\text { WOMAC } \\
\text { LEQUENSE } \\
\text { QUESTIONNAIO } \\
\text { RE }\end{array}$ & $\begin{array}{l}7 / 10 \\
1 b\end{array}$ \\
\hline 12 & $\begin{array}{l}\text { Effect of length on laterally wedge } \\
\text { insoles in knee osteoarthritis. }{ }^{[21]}\end{array}$ & Comparative study & 13 & $\begin{array}{l}\text { Vicon motion } \\
\text { analysis system }\end{array}$ & $\begin{array}{l}5 / 10 \\
2 b\end{array}$ \\
\hline 13 & $\begin{array}{l}\text { The effect of various kinds of lateral } \\
\text { wedge insoles on performance of } \\
\text { individuals with knee joint osteoarthritis } \\
{[25]}\end{array}$ & $\begin{array}{l}\text { A randomized } \\
\text { controlled trial } \\
(2 \text { months })\end{array}$ & 36 & WOMAC & $\begin{array}{l}5 / 10 \\
1 b\end{array}$ \\
\hline 14 & $\begin{array}{l}\text { Lateral wedge insoles for medial knee } \\
\text { osteoarthritis : } 12 \text { month controlled trial } \\
\text { [24] }\end{array}$ & $\begin{array}{l}\text { A randomized } \\
\text { controlled trial (4 } \\
\text { months) }\end{array}$ & 200 & $\begin{array}{l}\text { NPRS } \\
\text { WOMAC }\end{array}$ & $\begin{array}{l}7 / 10 \\
2 b\end{array}$ \\
\hline 15 & $\begin{array}{l}\text { The effect of different elevation of } \\
\text { laterally wedge insoles with subtalar } \\
\text { strapping on medial compartmental } \\
\text { osteoarthritis of the knee }{ }^{[18]}\end{array}$ & $\begin{array}{l}\text { Prospective quasi- } \\
\text { experimental } \\
\text { evaluation }\end{array}$ & 62 & WOMAC & $\begin{array}{l}8 / 10 \\
2 b\end{array}$ \\
\hline 16 & $\begin{array}{l}\text { An optimal duration of daily wear for an } \\
\text { insole with subtalar strapping in patients } \\
\text { with varus deformity osteoarthritis of the } \\
\text { knee }\end{array}$ & $\begin{array}{l}\text { A randomized } \\
\text { controlled trial } \\
\text { ( } 2 \text { weeks })\end{array}$ & 81 & $\begin{array}{l}\text { LEQUESNE } \\
\text { INDEX } \\
\text { RADIOGRAPH } \\
\text { for femorotibial } \\
\text { angle }\end{array}$ & $\begin{array}{l}10 / 10 \\
1 b\end{array}$ \\
\hline
\end{tabular}

Figure 1: Preferred Reporting Items for systematic reviews and meta-analysis (PRISMA)

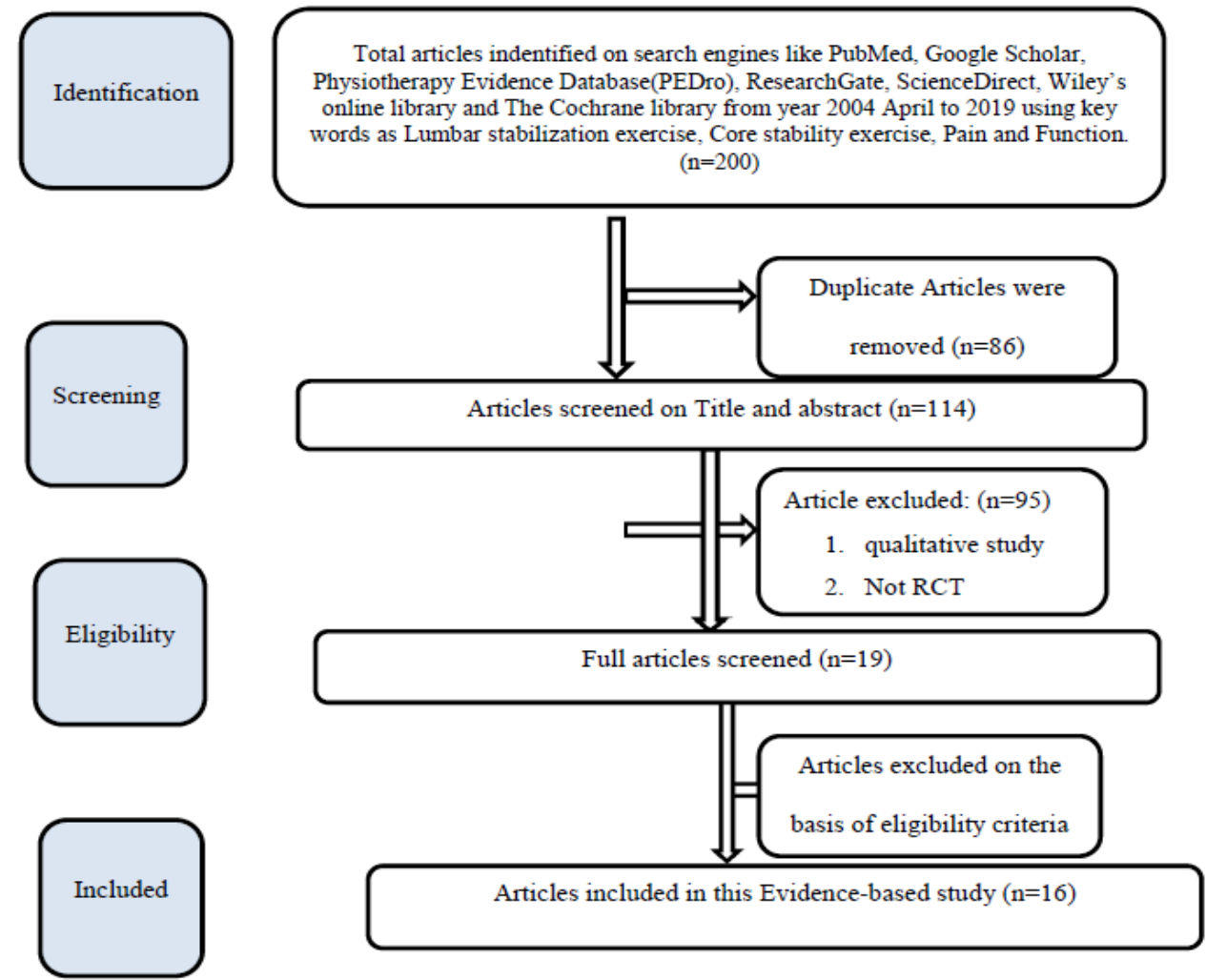

Data Analysis: All 16 articles were assessed using 2 scales:

(1). The PEDro scale: It assesses methodological quality and consists of a checklist of 11 criteria, 10 of which are scored. For each criterion the study met, 1 point was awarded. The points were tallied and presented as a score out of 10. The scale applies only to experimental studies. For this review, investigations with PEDro scores of 6 to 10 were considered high quality, of 4 to 5 were considered moderate quality, and of 0 to 3 were considered low quality. 
The PEDro score has demonstrated 'fair' to 'excellent' inter-rater reliability (Intraclass Correlation Coefficient 0.530.91) for randomized controlled trials of physiotherapy interventions. Convergent validity is supported for the PEDro score through correlation with other quality rating scales including: the Jadad scale (0.35) and van Tulder 2003 scale (0.71) for clinical trials of physiotherapy related interventions. ${ }^{[7]}$ (Appendix 1)

(2). The CEBM's Levels of Evidence scale: It assesses quality based on study design, which categorize the studies in a scale ranging from 1 to 5 with further subdivision for each. (Appendix 2)

\section{RESULTS}

Evidences were reviewed and analysis was done on the basis of PEDro score and CEBM's Level of Evidence Scale.

Total 200 articles were found, out of which 19 articles were relevant and from those 16 articles were included in this evidence-based study and other articles were excluded as per eligibility criteria. From total 16 studies, there are 2 meta analysis of RCT(1a),1 systemic review and meta analysis (1a),7 randomized controlled trial (1b),3 prospective randomized study(2b),1 comparative study (2b) shown that lateral wedge insole has significant effect on medial compartment knee osteoarthritis when compared to general (conservative) treatment and when combined with other exercises. Their Level of evidence was $1 \mathrm{a}, 1 \mathrm{~b}$ and $2 \mathrm{~b}$.

2 out of 16 ( 1 systematic review and 1 randomized controlled trial) studies. Their Level of evidence $1 \mathrm{a}$ and $1 \mathrm{~b}$. Their results showed that lateral wedge insole has same effect as neutral insole or as a placebo rather than actual effect on knee osteoarthritis. Which make it use of lateral wedge insole still controversial for use.

\section{DISCUSSION}

Total 16 studies were included in this evidence-based study. The methodological qualities of included studies were low to high. The sample size varied from 20-938 subjects.

Total 16 studies were reviewed from various search engines and included in this evidence-based study.

14 articles concluded that lateral wedge insole is effective in medial compartment osteoarthritis. (level of evidences: $1 \mathrm{a}, 1 \mathrm{~b}, 2 \mathrm{~b}$ )

There are 3 strong scientific evidences (Meta analysis and systemic review) suggests that optimal angle of wedge that best for $\mathrm{OA}$ is with the lowest possible degree lateral wedge insole which cause overall reduction in biomechanical parameters.

There are 11 moderate to high quality of evidences (RCT, A prospective randomized study and pre-post comparative study) suggests that by placing the wedge under sole of foot which is angulated so that it is thicker over lateral side than medial edge, transferring loading during weight bearing from medial to lateral knee compartment.

So compared to control group lever arm of (GRF) Ground reaction force in frontal plane at knee get reduced with lateral wedge insole.

This study found that using 8 to 12 $\mathrm{mm}$ elevation wedge with subtalar strapping is more comfortable for daily use with optimal duration of 8 to $10 \mathrm{hrs}$ in a day, full length and not just heel wedge insole is important as entire lateral border of foot is a key feature of the knee adduction moment for reducing loading.

2 Article concluded that there is no effect of lateral wedge insole in medial compartment osteoarthritis knee. (level of evidences : 1a,1b)

There is 1 strong evidence and 1 high quality of evidence which concluded that effect of lateral wedge insole was very small and clinical significance in only a minority of patients.

\section{CONCLUSION}

Based on the evidences taken from search engines: PubMed, Google Scholar, 
Physiotherapy Evidence Database(PEDro), ResearchGate, ScienceDirect, Wiley's online library and The Cochrane library of year 2005-2019 and analysis of all concluded that, full length wedge insole is found to be an effective conservative treatment for reducing pain and improving function in medial compartment knee osteoarthritis.

\section{Abbreviations}

PEDro: Physiotherapy Evidence Database, CEBM: Center of Evidence Based Medicine, PRISMA: Preferred Reporting Items for systematic reviews and metaanalysis, OA: osteoarthritis, KAM: knee adduction moments (KAM), FPI: Foot posture index, MCL: Medial collateral ligament, LCL: lateral collateral ligament, ACL: Anterior cruciate ligament, PCL: Posterior cruciate ligament, LWI: lateral wedge insole, NI: Neutral insole, WOMAC: Western Ontario and momaster universities osteoarthritis index, VAS: Visual analogues scale, FTA: Femorotibial angle, KOOS: Knee injury and osteoarthritis, TUG: Timed up and go test, NMT: Neuromuscular training, NPRS: Numeric pain rating scale.

\section{Acknowledgement: None}

Conflict of Interest: There is no conflict of interest.

\section{Source of Funding: None}

Ethical Approval: Ethical approval was not required.

\section{REFERENCES}

1. Chandra shekhar azad et al. - Osteoarthritis in India: An epidemiologic aspect. International journal of recent scientific research. IJRSR Vol. 8, Issue 10, Oct, 2017.

2. Harish kumar, Chandra p. Pal et al. Epidemiology of knee OA using kellgren \& Lawrence scale in Indian population. Journal of clinical orthopaedics and traumaVol.11 May-2019.
3. Chandra Prakash Pal 1, Pulkesh Singh 2, Sanjay Chaturvedi3 Epidemiology of knee osteoarthritis in India and related factors.Indian journal of orthopaedics 2016.

4. Donetry $\mathrm{M}$ jones $\mathrm{A}$, Cawston $\mathrm{T}$, OT in, Oxford textbook of rheumatology, 3rd edition

5. Ratzlaff $\mathrm{Cr}$, lifetime physical activity and osteoarthritis.Ph.D.thesis, the university of british Columbia, 2011

6. A mhajan, $\mathrm{S}$ varma, $\mathrm{V}$ tendon.Osteoarthritis. Journal of the association of physicians of india 2005,

7. Stephanie J. Crenshaw, MS;Fabian E. Pollo, $\mathrm{Ph} \mathrm{D}$ Effect of lateral wedge insole on kinetics at the knee,-Clinical Orthopaedics and related research Number 375

8. Kisner Carolyn, Colby Lynn allenTherapeutic exercise 5th edition

9. Cynthia C. Norkin-Joint structure and function 5 th edition

10. Matthew J. Parkes et al. Lateral wedge insoles as a conservative treatment for pain in patients with medial knee osteoarthritis. JAMA 2013.

11. B. D. Chaurasiya, human anatomy, 4th edition, volume 2

12. Altman R. et al. Development of criteria for the classification and reporting of osteoarthritis. Classification of osteoarthritis of the knee. Diagnostic and Therapeutic Criteria Committee of the American Rheumatism Association. Arthritis Rheum. 1986 Aug;29(8):1039-49. doi: 10.1002/art.1780290816.

13. Sullivan o, Schmitz, textbook of physical rehabilitation, chapter 26- arthritis

14. Vitor Ferreira et al. The optimal degree of lateral wedge insoles for reducing knee joint load: a systematic review and meta-analysis. Archives of physiotherapy, December 2019.

15. Bing bing Zhang, Xing Yu, Long Liang, Liguo Zhu, Xiaopeng Dong, Yang Xiong, Quan Pan, and Yongsheng Sun. Is the Wedged Insole an Effective Treatment Option When Compared with a Flat (Placebo) Insole: A systemic review and metaanalysis. Evidence - Based Complementary and Alternative Medicine 2018

16. Junfeng zhang et al. Ineffectiveness of lateral wedge insoles on the improvement of pain and function for medial knee osteoarthritis: a meta-analysis of controlled 
randomized trials. Arch ortho trauma surg. 2018 OCT.

17. Matthew J. Parkes, bsc; Nasimah Maricar, msc; Mark Lunt, phd. Lateral Wedge Insoles as a Conservative Treatment for Pain in Patients With Medial Knee Osteoarthritis-AMeta-analysis. JAMA 2013.

18. Y. Toda M.D., N. Tsukimura P.T. The effect of different elevation of laterally wedge insole with subtalar strapping on medial compartment osteoarthritis of the knee. Arch Phys Med Rehabil Vol 85, April 2004

19. Gustavo constantino de campos et al. Sao paulo med. Lateral wedge insole knee osteoarthritis: Randomized clinical trial. Sao Paulo Medical Journal. OCT 2014.

20. Ru-Lan Hsieh (MD), Wen-Chung Lee( MD) Clinical effect of lateral wedge arch support insole in knee osteoarthritis, A prospective double-blind randomized study. MEDICINE (July 2016).

21. Rana S. Hinman, Kelly ann Bowles and kim L Bennell, Laterally wedge insoles in knee osteoarthritis: do biomechanical effects decline after one month of wear?, BMC Musculoskeletal Disorders. 2009 Nov 25.

22. M.T.Khan, A comparative study of the effects of lateral wedge insole shoe modification on the patients with knee osteoarthritis., Osteoarthritis and Cartilage, April 2018 volume 26.

23. Y. Toda M.D., et al. An optimal duration of daily wear for an insole with suntalar strapping in patients with varus deformity osteoarthritis of the knee. Osteoarthritis and Cartilage 2005.

24. Kim L bennell, professor, kelly-Ann bowles, research scientist., Lateral wedge insole for medial knee osteoarthritis: 12 month randomised contolled trial, BMJ 2011.
25. Masoud rafiee and mohmamad $\mathrm{T}$ karimi., The effect of various kinds of lateral wedge insoles on performance of individuals with knee joint osteoarthritis. International journal of preventive medicine.2012.

26. Prof. Jim richard, prof. Rich jones A comparison of the biomechanical effect of valgus knee braces and lateral wedge insoles in patients with knee osteoarthritis Pre-post intervention Comparative study. Gait \& posture (2013).

27. Gillian L. Hatfield, Christopher K. Cochrane, judit takacs. Effect of length on laterally wedge insoles in knee osteoarthritis Knee and ankle biomechanics with lateral wedges with and without a custom arch support in those with medial knee osteoarthritis and flat feet. Journal of Orthopaedic Research. 22 January 2016, Volume 34..

28. David T. Felson, matthew parkes, suzane carter, Anmin liu, Michael callaghan.The efficacy of a lateral wedge insole for painful medial knee osteoarthritis after prescreening: A randomized clinical trial. Arthritis \& Rheumatology 2019, Volume 71.

29. Dr Victoria D Kuttan1, Dr Deepak B Anap., Feasibility of Lateral Wedge Insole v/s Neutral Insole in combination with Neuromuscular Training on Pain and Function in patients with Medial Compartment Osteoarthritis of Knee - a Pilot Double Blinded Randomized Control Trial. Indian journal of basic \&applied medical researcher, September 2019.

How to cite this article: Rajwadi MH, Shukla YU. Effect of lateral wedge insole on pain and function in medial compartment osteoarthritis knee- an evidence based study. International Journal of Science \& Healthcare Research. 2021; 6(2): 325-331. DOI: https://doi.org/10. 52403/ijshr.20210458

\section{APPENDIX 1-PEDro SCALE}

\begin{tabular}{|l|l|l|}
\hline No. & Description & Yes / No \\
\hline $\mathbf{1}$ & Eligibility criteria were specified (No points awarded) & \\
\hline $\mathbf{2}$ & Subjects were randomly allocated to groups & \\
\hline $\mathbf{3}$ & Allocation was concealed & \\
\hline $\mathbf{4}$ & The groups were similar at baseline regarding the most important prognostic indicators & \\
\hline $\mathbf{5}$ & There was blinding of all subjects & \\
\hline $\mathbf{6}$ & There was blinding of all therapists who administered the therapy & \\
\hline $\mathbf{7}$ & There was blinding of all assessors who measured at least one key outcome & \\
\hline $\mathbf{8}$ & Measure of at least one key outcome were obtained from more than 85\% of the subjects initially allocated to groups & \\
\hline $\mathbf{9}$ & All subjects for whom outcome measures were available received the treatment or control condition as allocated & \\
\hline $\mathbf{1 0}$ & The result of between group comparisons are reported for at least one key outcome & \\
\hline $\mathbf{1 1}$ & The study provides both point measures and measures of variability for at least one key outcome & \\
\hline
\end{tabular}


Mausmee Hemantbhai Rajwadi et.al. Effect of lateral wedge insole on pain and function in medial compartment osteoarthritis knee- an evidence based study.

APPENDIX 2- CEBM'S LEVEL OF EVIDENCE

\begin{tabular}{|l|l|}
\hline Level & Definition \\
\hline 1a & Systematic reviews of randomized controlled trials \\
\hline 1b & Individual randomized controlled trials \\
\hline 1c & All-or-none studies \\
\hline 2a & Systematic reviews of cohort studies \\
\hline 2b & Individual cohort studies or low-quality randomized controlled trials \\
\hline 2c & Outcome research \\
\hline 3a & Systematic reviews of case-control studies \\
\hline 3b & Individual case-control studies \\
\hline $\mathbf{4}$ & Case series, poorly designed cohort or case-control studies \\
\hline $\mathbf{5}$ & Animal and bench research, expert opinion \\
\hline
\end{tabular}

$* * * * * *$ 